\title{
PENINGKATAN MINAT TERHADAP HASIL BELAJAR PESERTA DIDIK MELALUI MEDIA PERMAINAN ULAR TANGGA PADA PELAJARAN KEWIRAUSAHAAN DI SEKOLAH MENENGAH KEJURUAN
}

(Studi penelitian peserta didik Kelas X di lokasidi Jakarta Timur, Tangerang Selatan, dan Depok)

\author{
Askardiya Mirza Gayatri dan Septiana Ika Ningtyas \\ Dosen Program Studi Pendidikan Ekonomi Universitas Indraprasta PGRI \\ E-mail :mirzagayatri@yahoo.com
}

\begin{abstract}
Abstrak
Kewirausahaan di sekolah seringkali menjadi pelajaran yang dinomor duakan, selain jam belajarnya sedikit, keantusiasan peserta didik dalam menerima materi juga masih rendah.Salah satu penyebabnya karena metode atau cara mengajarnya yang monoton sehingga peserta didik merasa bosan dan kurang tertarik. Penelitian ini bertujuan untuk mengetahui bagaimana meningkatkan minat peserta didik pada pelajaran kewirausahaan melalui media permainan ular tangga sehingga berdampak pada hasil belajarnya. Media permainan ular tangga ini dimaksudkan untuk merangsang antusiasme peserta didik dengan metode pembelajaran yang menarik dan menyenangkan. Melalui permainan yang menyenangkan diharapkan otak dapat menyimpan memori materi pelajaran lebih lama dan dalam jangka panjang media permainan ular tangga ini dapat digunakan pada pelajaran lainnya seperti matematika,fisika, bahasa dan sebagainya sehingga peserta didik mencapai keberhasilan belajar yang optimal. Bentuk pre test dan tes formatif digunakan untuk mengukur hasil belajar siswa sebelum dan sesudah menggunakan media permainan ular tangga pada pelajaran kewirausahaan sedangkan bentuk angket digunakan untuk mengukur minat belajar peserta didik. Penelitian ini dilaksanakan pada Sekolah Menengah Kejuruan (SMK) yang ada di wilayah Jakarta, Depok, dan Tangerang Selatan dengan waktu penelitian dari bulan Mei sampai dengan Agustus 2017. Teknik pengambilan sampel pada penelitian ini adalah teknik sampel acak terstratifikasi yaitu mengambil sampel secara acak melalui kelompok di kelas X dari ketiga sekolah tersebut. Dari hasil penelitian ini ingin didapatkan peningkatan minat terhadap hasil belajar peserta didik kelas X melalui media permainan ular tangga.
\end{abstract}

Kata Kunci: Minat Belajar, Hasil Belajar, Permainan Ular Tangga, Pelajaran Kewirausahaan

\section{PENDAHULUAN}

Perkembangan zaman yang semakin modern terutama era globalisasi seperti yang dihadapi saat ini menuntut sumber daya yang kompeten tidak hanya dalam segi ilmu pengetahuan tetapi juga tanggap terhadap perubahan serta dapat beradaptasi dengan cepat.Peningkatan kualitas sumber daya merupakan salah satu syarat tercapainya tujuan pembangunan. Salah satu cara untuk meningkatkan kualitas sumber daya adalah melalui pendidikan.

Peningkatan mutu pendidikan salah satunya terdapat di sekolah melalui keberhasilan proses belajar mengajar. Proses belajar mengajar tersebut dipengaruhi oleh beberapa komponen yaitu guru, peserta didik, metode serta media pembelajaran. Seorang guru memiliki peranan penting dalam membentuk karakter peserta didik, bukan hanya mengajar tetapi juga mendidik dan menanamkan nilai-nilai positif yang dapat ditiru. 
Peserta didik yang menjadi objek dalam proses belajar mengajar, diharapkan memiliki kualitas unggul serta dapat bersaing dalam pasar global. Metode pembelajaran dalam hal ini adalah cara atau langkah yang digunakan guru dalam proses belajar mengajar guna tercapainya tujuan pembelajaran. Media pembelajaran sebagai alat yang menyampaikan atau mengantarkan pesan pembelajaran dan juga salah satu faktor tercapainya keberhasilan belajar mengajar.

Dalam kegiatan belajar mengajar media pembelajaran digantikan dengan istilah-istilah seperti bahan pengajaran, alat peraga pandang, dan media pandang. Seperti yang dikatakan Arsyad (2016: 6) "Media pendidikan dapat digunakan secara massal (misalnya: radio, televisi), kelompok besar dan kelompok kecil (misalnya film, slide, video,OHP), atau perorangan (misalnya:modul, komputer, radio tape / kaset, video recorder)."

Peserta didik yang menggunakan media dalam proses belajarnya seperti alat peraga atau pemutaran video akan menghasilkan nilai lebih. Seperti yang diungkapkan Levie \& Levie dalam Arsyad (2016: 12) yang membaca kembali hasil belajar melalui stimulus gambar dan stimulus kata atau visual dan verbal menyimpulkan bahwa: Stimulus visual membuahkan hasil belajar yang lebih baik untuk tugas-tugas seperti mengingat, mengenali, mengingat kembali, dan menghubung-hubungkan fakta dan konsep sementara verbal memberikan hasil belajar yang lebih apabila pembelajaran itu melibatkan ingatan yang berurut-urutan (sekuensial).

Hal ini menunjukkan bahwa belajar dengan menggunakan indera ganda pandang dan dengar. Peserta didik akan belajar lebih banyak daripada jika materi pelajaran disajikan hanya dengan stimulus pandang atau hanya dengan stimulus dengar.

Media pembelajaran yang digunakan dibuat menarik agar peserta didik dapat memahami dengan mudah materi yang disampaikan.Peneliti memilih media pembelajaran berupa permainan yaitu jenis permainan tradisional seperti permainan ular tangga. Permainan ular tangga dapat menjadi media pembelajaran yang efektif karena sifat permainannya yang sederhana dan mengasyikkan dapat membuat peserta didik antusias dalam bermain (M.Husna A, 2009 : 143).

Permainan ular tangga ini digunakan selama proses pembelajaran sebagai sarana bagi peserta didik untuk mengembangkan potensi sekaligus sebagai pengerjaan evaluasi pada materi kewirausahaan di SMK kelas $\mathrm{X}$ tentang konsep kewirausahaan serta 
karakateristik seorang wirausaha dalam bentuk tanya jawab/ kuis. Materi-materi yang ada dalam pelajaran kewirausahaan akan menjadi sangat menarik jika menggunakan media ular tangga karena selain bersifat interaktif, permainan ular tangga juga melatih jiwa kompetitif serta sportif yang diharapkan dapat menimbulkan jiwa persaingan yang sehat diantara para peserta didik.

Berdasarkan uraian latar belakang permasalahan tersebut, peneliti mencoba melakukan penelitian tentang peningkatan mi permainan ular tangga di tiga (3) SMK yaitu: SMK Respati 2, Jakarta Timur; SMK Waskito Pamulang, Tangerang Selatan; dan SMK Semesta, Cimanggis, Depok.

\section{METODE}

Metode yang digunakan dalam penelitian ini adalah metode eksperimen permainan dimana peneliti menggunakan media permainan ular tangga yang dapat menstimulasi minat peserta didik untuk belajar yang nantinya akan berdampak pada hasil yang didapatkan peserta didik dalam pelajaran kewirausahaan.

Data yang diperlukan dalam penelitian ini adalah data primer dan data sekunder yang diperoleh dari narasumber yang diperlukan yaitu guru pelajaran kewirausahan dan peserta didik kelas X di tiga SMK yaitu SMK Waskito Tangerang Selatan, SMK Semesta Cimanggis Depok, dan SMK Respati 2 Jakarta Timur Pada penelitian ini, peneliti menggunakan teknik pengumpulan data dengan observasi lapangan, teknik tes (pre test, test formatif), dokumentasi dan pengisian lembar angket.

Adapun alat pengumpul data yang digunakan dalam penelitian ini ada dua yaitu: soal tes dan lembar angket. Jenis soal yang akan digunakan dalam pre test yaitu soal isian singkat yang berjumlah 10 butir pertanyaan, kemudian jenis soal yang digunakan dalam tes formatif dibagi menjadi 2 yaitu: 10 soal pilihan ganda dan 10 soal uraian. Sedangkan lembar angket diberikan kepada peserta didik untuk mengetahui minat belajar.Lembar angket berisi 20 pertanyaan yang harus dijawab oleh peserta didik.

\section{TINJAUAN PUSTAKA}

\section{Pengertian Minat Belajar}

Untuk mendapatkan prestasi yang baik tidak hanya diperlukan pemahaman terhadap suatu materi, tidak juga hanya diperlukan kecerdasan namun juga minat terhadap 
suatu materi. Tanpa disertai minat, peserta didik tidak akan antusias dalam menerima materi pelajaran. Menurut Suhartini (2012) “minat adalah penerimaan akan suatu hubungan antara diri dan sesuatu di luar diri”.Suatu minat dapat diekpresikan melalui suatu pernyataan bahwa peserta didik lebih menyukai suatu hal daripada hal lainnya.

Minat dapat pula diwujudkan melalui peran serta peserta didik dalam aktivitas dimana siswa yang berminat terhadap objek tertentu cenderung memberikan perhatian yang lebih besar terhadap objek tersebut.Selanjutnya menurut Sudaryono, Margono dan Rahayu (2012: 90) "minat adalah kesadaran yang timbul bahwa objek tertentu sangat disenangi dan melahirkan perhatian yang tinggi bagi individu terhadap objek tertentu. Kemudian ditambahkan oleh Tidjan dalam Hariyanto (2010) mengemukakan bahwa “minat adalah gejala psikologis yang menunjukkan pemusatan perhatian terhadap suatu objek, sebab ada perasaan senang.Slameto (2013: 180) mengemukakan, “minat adalah suatu rasa lebih suka dan suatu rasa ketertarikan pada suatu hal atau aktivitas, tanpa ada yang menyuruh”.

Belajar diartikan oleh Slameto (2010: 2) “adalah suatu proses usaha yang dilakukan seseorang untuk memperoleh suatu perubahan tingkah laku yang baru secara keseluruhan sebagai hasil pengalamannya sendiri dalam interaksi dengan lingkungannya”. Menurut Gagne seperti yang dikutip Syah, Darwyan. Dkk (2009: 35) bahwa "belajar adalah suatu proses untuk memperoleh modivikasi dalam pengetahuan, keterampilan, kebiasaan yang diperoleh dari interaksi”. Sehingga dapat disimpulkan minat belajar adalah adanya perasaan senang dan rasa ketertarikan yang muncul dari dalam individu untuk melakukan proses perubahan tingkah laku sebagai hasil pengalaman dan interaks terhadap lingkungannya.

\section{Pengertian Hasil Belajar}

Menurut Snelbeker dalam Rusmono (2012: 8) mengatakan “perubahan atau kemampuan baru yang diperoleh siswa setelah melakukan perbuatan belajar merupakan hasil belajar. Karena pada dasarnya adalah bagaimana perilaku seseorang berubah sebagai akibat dari pengalaman”.Kemudian ditambahkan oleh Rifa’i dan Anni (2009: 85) "hasil belajar merupakan perubahan perilaku yang diperoleh siswa setelah mengalami kegiatan belajar”.

Pada dasarnya hasil belajar menjadi salah satu tolak ukur keberhasilan suatu pembelajaran, melalui kegiatan evaluasi maka akan terlihat sejauh mana peserta didik 
memahami apa yang telah disampaikan gurunya. Hasil belajar menurut Dimyati dalam Ranti (2007: 12) adalah "hasil proses belajar di mana pelaku aktif dalam belajar adalah siswa dan pelaku aktif dalam pembelajaran adalah guru”. Hal tersebut didukung oleh Nana Sudjana (2005: 3) "hasil belajar adalah perubahan tingkah laku siswa setelah melalui proses pembelajaran”.

Gagne dalam Dahar (2006: 118) mengkategorikan lima kemampuan sebagai hasil belajar diantaranya : Kemampuan pertama disebut keterampilan intelektual, karena keterampilan itu merupakan penampilan yang ditunjukkan oleh siswa tentang operasi intelektual yang dpaat dilakukannya.Kemampuan kedua meliputi penggunaan strategi kognitif, karena siswa perlu menunjukkan penampilan yang kompleks dalam suatu situasi baru dimana diberikan sedikit bimbingan dalam memilih dan menerapkan aturan dan konsep yang telah dipelajari sebelumnya.Kemampuan ketiga berhubungan dengan sikap atau mungkin sekumpulan sikap yang dapat ditunjukkan oleh perilaku yang mencerminkan pilihan tindakan terhadap kegiatan-kegiatan sains.Kemampuan keempat ialah informasi verbal dan yang terakhir yaitu keterampilan motorik.

Berdasarkan beberapa teori yang dikemukakan di atas dapat disimpulkan pengertian hasil belajar adalah perubahan perilaku individu yang meliputi aspek kognitif, afektif dan psikomotor yang diperoleh setelah mengalami kegiatan belajar.

\section{Media Pembelajaran}

Seiring berkembangnya ilmu pengetahuan maka guru juga dituntut untuk menggunakan media dalam proses belajar mengajarnya karena media adalah bagian yang tidak terpisahkan dari proses belajar mengajar demi tercapainya tujuan. Menurut Arsyad (2016: 3) : “media berasal dari bahasa latin medius yang secara harfiah artinya tengah, perantara, atau penghantar.” Hal senada juga diungkapkan Gerlach \& Elye (dalam Arsyad 2011: 3) bahwa media secara garis besar adalah "manusia, materi atau kejadian yang membuat siswa mampu memperoleh pengetahuan, keterampilan, atau sikap.”

Media pembelajaran merupakan semua sumber yang diperlukan untuk melakukan komunikasi dengan pembelajaran.Gagne (dalam Sadiman, 2002: 6) menyatakan “media adalah berbagai jenis komponen dalam lingkungan siswa yang dapat merangsangnya untuk belajar."Salah satu media pembelajaran adalah media proyeksi yaitu permainan dan simulasi.Peneliti memilih menggunakan media pembelajaran dengan permainan. Menurut Yulianty (2011: 7) bermain merupakan suatu proses alamiah yang dengan 
sendirinya dilakukan oleh anak-anak. Melalui suatu permainan diharapkan peserta didik dapat memperoleh kesenangan tanpa ada keterpaksaan. Seperti yang diungkapkan Seels \& Glasgow (1990) dalam Arsyad (2016: 35), pengelompokkan media terbagi menjadi dua kategori luas, yaitu: pilihan media tradisional (dimana terdapat permainan seperti teka-teki, simulasi dan permainan papan) dan pilihan media teknologi mutakhir.

Menurut Sardiman (2002: 75) mengatakan bahwa permainan adalah setiap kontes antara pemain yang berinteraksi satu sama lain dengan mengikuti aturan tertentu untuk mencapai tujuan tertentu. Dengan demikian melalui permainan dapat disisipkan materi pelajaran sehingga peserta didik dapat belajar sekaligus bermain.Sadiman (2002: 78) juga menjelaskan permainan adalah sesuatu yang menyenangkan untuk dilakukan, sesuatu yang menghibur.Sehingga dapat disimpulkan media pembelajaran adalah bentuk komponen yang dapat menstimulasi peserta didik untuk belajar.

\section{Pelajaran Kewirausahaan.}

Pelajaran kewirausahaan yang diberikan di SMK sebagai salah satu bentuk dalam rangka memasyarakatkan dan membangkitkan semangat kewirausahaan di Indonesia, sesuai dengan Instruksi Presiden (Inpres) RI Nomor 4 Tahun 1995 tanggal 30 Juni 1995 tentang Gerakan Nasional Memasyarakatkan dan Membudayakan Kewirausahaan (GNMMK), yang isinya: "Kewirausahaan adalah semangat, sikap, perilaku, dan kemampuan seseorang dalam menangani usaha atau kegiatan yang mengarah pada upaya cara kerja, teknologi dan produk baru dengan meningkatkan efisiensi dalam rangka memberikan pelayanan yang lebih baik dan keuntungan yang lebih besar”.

Mata pelajaran kewirausahaan di SMK Kelas X yang belum memberlakukan Kurikulum 2013, diberikan di semester 1 dan 2 pada semua program keahlian. Dalam silabus di SMK Kelas X, tertuang standar kompetensi yaitu dengan mengaktualisasikan sikap dan perilaku wirausaha.

Adapun kompetensi dasar di semester 1 (satu) yaitu:

1. mengidentifikasi sikap dan perilaku wirausaha;

2. menerapkan sikap dan perilaku kerja prestatif;

3. merumuskan solusi masalah; dan

4. mengembangkan semangat wirausaha.

Sedangkan di semester 2 (dua) kompetensi dasarnya yaitu:

1. membangun komitmen tinggi bagi dirinya dan orang lain; 
2. mengambil resiko usaha; dan

3. membuat keputusan.

Menurut Drucker (1959) dalam Rusdiana (2014: 45), kewirausahaan adalah kemampuan untuk menciptakan sesuatu yang baru dan berbeda. Pengertian tersebut dapat diartikan sebagai seseorang yang memiliki kemampuan untuk menciptakan sesuatu yang baru, berbeda dari yang lainnya atau berbeda dari yang sebelumnya.Zimmerer dan Scarborough (2005: 42),mengatakan bahwa kewirausahaan merupakan hasil dari proses disiplin dan sistematis dalam menerapkan kreativitas dan inovasi terhadap kebutuhan dan peluang dalam pasar. Dari pengertian kewirausahaan di atas dapat disimpulkan bahwa kewirausahaan adalah suatu kemampuan menciptakan kegiatan usaha melalui gagasangagasan yang kreatif dan inovatif.

\section{HASIL DAN PEMBAHASAN}

Hasil yang dicapai dalam pelaksanaan penelitian ini adalah sebagai berikut:

\section{1) SMK Waskito, Pamulang, Tangerang Selatan}

Dari pelaksanaan pre-test yang diujikan pada tanggal 10 Mei 2017 di kelas X AK 1 dan X AK 2 SMK Waskito, Pamulang, hasil menunjukkan bahwa pemahaman peserta didik terhadap materi Kewirausahaan masih belum sepenuhnya terlampaui, hal ini dibuktikan dengan masih rendahnya hasil pre-test yang mereka kerjakan, hasil pre test menunjukkan bahwa hampir 75\% siswa mendapatkan skor $<50$, sehingga hal tersebut memotivasi peneliti bahwa haruslah dilakukan uji coba dan treatment berupa materi, penjelasan tanya jawab dan bermain peran dalam media ular tangga, dari hasil treatment tersebut terlihat keantusiasan para peserta didik untuk melihat, mencoba serta berperan aktif dalam penggunaan media pembelajaran yang baru tersebut. Antusias yang mereka tunjukkan selama berlangsungnya pembelajaran secara tidak langsung membuat mereka ingin tahu lebih banyak serta terus menggali informasi dan sumber mengenai mata pelajaran kewirausahaan. Bukan hanya itu, peneliti juga menstimulus mereka untuk menyampaikan ide secara berkelompok untuk membuat sebuah konsep usaha yang dapat mereka kembangkan nantinya, ide tersebut haruslah orisinil dan inovatif sehingga diharapkan para peserta didik dapat mewujudkan konsep usaha tersebut di masa mendatang. 
Setelah dilakukan pre-test, treatment yang dilakukan peneliti selanjutnya adalah memberikan tes formatif pada tanggal 30 Mei 2017 tujuannya adalah untuk mengetahui seberapa jauh pemahaman mereka mengenai materi yang telah disampaikan di pertemuan sebelumnya, seberapa besar pengaruh penggunaan media pembelajaran ular tangga terhadap minat peserta didik dalam berwirausaha serta menumbuhkan jiwa dan semangat berwirausaha sejak dini. Hasil test formatif menunjukkan bahwa adanya peningkatan yang cukup signifikan dibandingkan dengan pre-test yang dilakukan sebelumnya, hal ini dibuktikan dari hasil yang cukup memuaskan dimana persentase keberhasilan mencapai hampir 80\% dari seluruh peserta didik (Hasil test formatif terlampir), Penggunaan media pembelajaran seperti ular tangga yang diterapkan peneliti membuat peserta didik selalu terlihat antusias dan menyenangkan sehingga materi-materi yang disampaikan pun mudah diresapi. Peningkatan dan penguatan minat berwirausaha yang dilakukan oleh peneliti untuk peserta didik tujuannya adalah agar peserta didik dapat menentukan ide kreatif serta peluang usaha apa yang akan diterapkan nantinya selain lulus sekolah. Pengisian angket dilaksanakan pada 29 Juli 2017. Hasil pengolahan data membuktikan bahwa adanya pengaruh positif antara minat dan hasil belajar peserta didik melalui media permainan ular tangga pada mata pelajaran kewirausahaan di Sekolah Menengah Kejuruan dimana hasil perhitungan uji validitas menghasilkan $r$ hitung $>r$ tabel sehingga menghasilkan variabel yang diujikan valid sedangkan pada uji reliabilitas varian butir menunjukkan angka 9,715 dan alpha cronbach sebesar 0,845 yang berarti menunjukkan sangat andal.

Dapat disimpulkan bahwa pengaruh minat dan hasil belajar peserta didik melalui media permainan ular tangga pada mata pelajaran kewirausahaan dinyatakan berpengaruh sangat signifikan. Hal ini dibuktikan dengan perolehan hasil olah data yang menunjukkan alpha cronbach adalah 0,845 yang mengindikasikan tingkat kehandalan/ reliabilitas tinggi. Penggunaan media pembelajaran ular tangga mampu meningkatkan minat peserta didik kelas $\mathrm{X}$ dalam mata pelajaran kewirausahaan di Sekolah Menengah Kejuruan.

\section{2) SMK Semesta, Cimanggis, Depok}

Dari pelaksanaan pre-test yang diujikan pada tanggal 5 Juni 2017 di kelas X AK 1 dan $\mathrm{X}$ AK 2 SMK Semesta Cimanggis, Depok, hasil menunjukkan bahwa 
pemahaman peserta didik terhadap materi Kewirausahaan masih belum sepenuhnya terlampaui, hal ini dibuktikan dengan masih rendahnya hasil pre-test yang mereka kerjakan, total dari keseluruhan siswa kelas X sebanyak 70\% mendapatkan skor antara 40-60, melihat hal tesebut maka, perlulah dilakukan ujicoba dan stimulus berupa materi, tanya jawab dan media ular tangga, dari hasil treatment tersebut terlihat keantusiasan para peserta didik untuk melihat, mencoba serta berperan aktif dalam penggunaan media pembelajaran yang baru tersebut. Antusias yang mereka tunjukkan selama berlangsungnya pembelajaran secara tidak langsung membuat mereka ingin tahu lebih banyak serta terus menggali informasi dan sumber mengenai mata pelajaran kewirausahaan. Bukan hanya itu, peneliti juga menstimulus mereka untuk menyampaikan ide secara berkelompok untuk membuat sebuah konsep usaha yang dapat mereka kembangkan nantinya, ide tersebut haruslah orisinil dan inovatif. Setelah berdiskusi maka gambaran dari ide tersebut dipresentasikan di depan kelas sehingga melatih keberanian peserta didik untuk menyampaikan idenya di depan teman-teman sekelasnya.

Setelah dilakukan pre-test, treatment yang dilakukan peneliti selanjutnya adalah memberikan tes formatif pada tanggal 9 Agustus 2017 tujuannya adalah untuk mengetahui seberapa jauh pemahaman mereka mengenai materi yang telah disampaikan di minggu sebelumnya, seberapa besar pengaruh penggunaan media pembelajaran ular tangga terhadap minat peserta didik dalam berwirausaha serta menumbuhkan jiwa dan semangat berwirausaha sejak dini. Hasil test formatif menunjukkan bahwa adanya peningkatan yang cukup signifikan dibandingkan dari test yang dilakukan sebelumnya, dimana hasil yang dicapai sebesar $75 \%$ mendapatkan skor yang tinggi antara 70-85. Penggunaan media pembelajaran seperti ular tangga yang diterapkan peneliti membuat peserta didik selalu terlihat antusias dan menyenangkan sehingga materi-materi yang disampaikan pun mudah diresapi. Peningkatan dan penguatan minat berwirausaha yang dilakukan oleh peneliti untuk peserta didik tujuannya adalah agar peserta didik dapat menentukan ide kreatif serta peluang usaha apa yang akan diterapkan nantinya selain lulus sekolah. Pengisian angket dilaksanakan pada 15 Agustus 2017. Berdasarkan hasil pengolahan data uji validitas yang dilakukan menunjukkan hasil $r$ hitung> $r$ tabel berarti variabel yang diuji valid, uji reliabilitas menunjukkan hasil total varian butir sebesar 7,445 
sedangkan alpha cronbach 0,834 yang berarti mengindikasikan tingkat reliabilitas tinggi

Dapat disimpulkan bahwa pengaruh minat terhadap hasil belajar peserta didik kelas X melalui media permainan ular tangga di Sekolah Menengah Kejuruan berpengaruh sangat signifikan, berdasarkan hasil olah data dimana perhitungan alpha cronbach sebesar 0,834 yang berarti mngindikasikan tingkat keandalan pada variabel sangat tinggi. Media pembelajaran ular tangga mampu meningkatkan minat peserta didik dalam mata pelajaran kewirausahaan sehingga diharapkan memiliki keluaran dengan hasil belajar yang memuaskan dan makin meresapi bakat dan jiwa-jiwa usahawan agar dapat mengikuti jejak para usahawan muda yang telah mencapai keberhasilan.

\section{3) SMK Respati 2, Jakarta Timur}

Dari pelaksanaan pre-test yang diujikan pada tanggal 27 Juli 2017 di kelas X AK 1 dan X AK 2 SMK Respati, Jl. Inpres, Jakarta Timur hasil menunjukkan bahwa pemahaman peserta didik terhadap materi Kewirausahaan masih rendah, sama hanya ketika dilakukan uji coba di sekolah yang berbeda, pemahaman mereka terhadap kewirausahaan belum menyeluruh dimana hasil tes menunjukkan hanya 30\% siswa yang memahami dengan baik konsep kewirausahaan, dengan masih terbatasnya pemahaman peserta didik terhadap mata pelajaran kewirausahaan maka, peneliti perlu memberikan treatment berupa materi, tanya jawab dan papan ular tangga sebagai salah satu media untuk menunjang pembelajaran. Dari hasil treatment tersebut antusias para peserta didik untuk melihat, mencoba serta berperan aktif dalam penggunaan media pembelajaran tersebut. Antusias yang mereka tunjukkan selama berlangsungnya pembelajaran mengajak mereka untuk mencari tahu lebih banyak serta terus mencari informasi mengenai materi kewirausahaan. Bukan hanya itu, peneliti juga menstimulus mereka untuk menyampaikan ide secara berkelompok untuk membuat sebuah konsep usaha yang dapat mereka kembangkan nantinya, ide tersebut haruslah orisinil dan inovatif sehingga diharapkan para peserta didik dapat mewujudkan konsep usaha tersebut di masa mendatang.

Setelah dilakukan pre-test, treatment yang dilakukan peneliti selanjutnya adalah memberikan tes formatif pada tanggal 28 Agustus 2017 tujuannya adalah untuk 
mengetahui seberapa jauh pemahaman mereka mengenai materi yang telah disampaikan pada pertemuan sebelumnya, seberapa besar pengaruh penggunaan media pembelajaran ular tangga terhadap minat peserta didik dalam berwirausaha serta menumbuhkan jiwa dan semangat berwirausaha sejak dini. Hasil test formatif menunjukkan bahwa adanya peningkatan yang cukup signifikan dibandingkan dari test yang dilakukan sebelumnya, hal ini dibuktikan dari hasil yang cukup baik dimana dari hasil test formatif 80\% peserta didik memperoleh skor 70-80 (Hasil test formatif terlampir), Penggunaan media pembelajaran seperti ular tangga yang diterapkan peneliti membuat peserta didik selalu terlihat antusias dan menyenangkan sehingga materi-materi yang disampaikan pun mudah diresapi. Peningkatan dan penguatan minat berwirausaha yang dilakukan oleh peneliti untuk peserta didik tujuannya adalah agar peserta didik dapat menentukan ide kreatif serta peluang usaha apa yang akan diterapkan nantinya selain lulus sekolah. Pelaksanaan pengisian angket pada 31 Agustus 2017. Berdasarkan hasil pengolahan data uji validitas yang dilakukan menunjukkan hasil $r$ hitung> $r$ tabel berarti variabel yang diuji valid, uji reliabilitas menunjukkan hasil total varian butir sebesar 8,797 sedangkan alpha cronbach 0,623 yang berarti mengindikasikan tingkat reliabilitas cukup tinggi.

Dapat disimpulkan bahwa pengaruh minat terhadap hasil belajar peserta didik kelas X melalui media permainan ular tangga di Sekolah Menengah Kejuruan berpengaruh sangat signifikan, berdasarkan hasil olah data dimana perhitungan alpha cronbach sebesar 0,623 yang berarti mngindikasikan tingkat keandalan pada variabel cukup tinggi. Media pembelajaran ular tangga mampu meningkatkan minat peserta didik dalam mata pelajaran kewirausahaan sehingga diharapkan memiliki keluaran dengan hasil belajar yang memuaskan dan makin meresapi jiwa-jiwa usahawan agar dapat mengikuti jejak para usahawan muda yang telah mencapai keberhasilan.

\section{SIMPULAN}

Berdasarkan hasil penelitian, maka dapat disimpulkan bahwa minat hasil belajar peserta didik meningkat dengan menggunakan metode permainan ular tangga dilihat dari hasil test formatif sangat bagus setelah peserta didik diberikan treatment, dibandingkan hasil pre test yang belum diberikan treatment. 
Metode dan materi dalam penelitian yang tim sampaikan selain dengan cara bermain namun sarat dengan pengetahuan kewirausahaan baik berupa soft skill maupun hard skill sehingga peserta didik sangat senang dan antusias dalam belajar mata pelajaran kewirausahaan yang biasanya hanya berupa teori saja. Selain hal tersebut di atas peserta didik juga lebih sigap dan aktif karena pengajaran melalui media permainan ular tangga melaksanakan 3 (tiga) ranah, kognitf, afektif, dan psikomotor.

Pelaksanaan penelitian ini juga menghasilkan karya ilmiah yang akan dipublikasikan dan diharapkan menginspirasi dan bermanfaat bagi para guru, meskipun dalam pelaksanaannya terbatas waktu yang berdampak pada kurang maksimalnya pelaksanaan penelitian dikarenakan pihak sekolah memberikan jadwal yang hampir sama dengan jadwal di sekolah lain. Untuk pelaksanaan penelitian selanjutnya supaya lebih maksimal pelaksanaan dilakukan pada satu sekolah saja dengan waktu yang lebih lama seperti pada penelitian tindakan kelas.

\section{UCAPAN TERIMA KASIH}

Ucapan terima kasih kami ucapkan pada Kemenristekdikti atas Hibah Penelitian Dosen Pemula yang diterima oleh Tim PDP dosen Universitas Indraprasta PGRI sehingga tim dapat melaksanakan penelitian di tiga (3) Sekolah Menengah Kejuruan dengan lokasi penelitian di Tangerang Selatan, Depok, dan Jakarta Timur. Terima kasih juga kami ucapkan kepada Bapak Hartono. S.Si., M.Pd (Kepala SMK Waskito Pamulang, Tangerang Selatan), Ibu Enny S.H., M.M. (Kepala SMK Semesta, Cimanggis, Depok), dan Bapak Drs. Haryadi (Kepala SMK Respati 2, Jakarta Timur) yang telah memberikan ijin untuk melaksanakan penelitian di sekolahnya, serta tidak lupa kami ucapkan terima kasih kepada Ketua beserta Staff LP2M Universitas Indraprasta PGRI yang banyak membantu kami dalam memberikan masukan.

\section{DAFTAR PUSTAKA}

Arsyad, Azhar. 2016. Media Pembelajaran. Edisi Revisi. Jakarta: PT RajaGrafindo Persada.

Dahar, Ratna Wilis. 2006. Teori-teori Belajar dan Pembelajaran. Bandung: Erlangga.

Hariyanto. 2010. Pengertian Minat Belajar://belajarpsikologi.com/pengertian minat (diakses 20 April 2016) 
Husna, A. 2009.100 + Permainan Tradisional Indonesia untuk Kreativitas, Ketangkasan, dan Keakraban. Yogyakarta: Penerbit Andi.

Ranti. 2007. Penilaian Hasil Belajar. (http://one.indoskripsi.com) diunduh tanggal 8 Februari 2009.

Rifai, Achmad dan Catharina Tri Anni. 2009. Psikologi Pendidikan. Semarang:Universitas Negeri Semarang Press.

Rusmono. 2012. Strategi Pembelajaran Problem Based Learning Itu Perlu: UntukMeningkatkan Profesionalitas Guru. Bogor: Ghalia Indonesia.

Rusdiana. 2014. Kewirausahaan. Teori dan Praktik. Bandung: Penerbit PUSTAKA SETIA

Sardiman A.M. 2012. Interaksi \& Motivasi Belajar Mengajar. Jakarta: Rajawali.

Slameto. 2013. Belajar dan Faktor-Faktor yang Mempengaruhi. Jakarta: PT RINEKA CIPTA

Sudjana, Nana. 2010. Penilaian Hasil Proses Belajar Mengajar.Bandung: PT Remaja Rosdakarya.

Sudaryono, Margono dan Rahayu. 2012. Pengembangan Instrumen Penelitian Pendidikan. Yogyakarta: Graha Ilmu.

Suhartini. 2012. Minat Siswa Terhadap Topik-topik Mata Pelajaran Sejarah dan Beberapa Faktor yang Melatarbelakanginya. Disertasi.PPS Universitas Pendidikan Indonesia.

Syah, Darwyan. Supardi, Muslihah, Eneng. 2009. Strategi Belajar Mengajar. Jakarta: DIADIT MEDIA.

Yulianty, Rani. 2011. Permainan yang Meningkatkan kecerdasan Anak Modern dan Tradisional. Jakarta: Laskar Aksara.

Zimmerer, Thomas, dan Scarborough, Norman. 2005. Pengantar Kewirausahaan dan Manajemen Bisnis Kecil. Edisi Keempat. Edisi Bahasa Indonesia. Jakarta: PT Indeks, Kelompok Gramedia. 